\title{
FLAVOR BIOGENERATION IN MANGABA (Hancornia speciosa Gomes) FRUIT
}

\author{
BIOGERAÇÃO DE SABOR NA FRUTA MANGABA (Hancornia \\ speciosa Gomes)
}

\author{
NARENDRA NARAIN ${ }^{1}$ \\ MÉRCIADE S. GALVÃO \\ DANIEL DA S. FERREIRA ${ }^{3}$ \\ DANIELA M. A. F. NAVARRO ${ }^{4}$
}

\section{ABSTRACT}

\begin{abstract}
Most of the volatile flavoring substances are formed during maturation of fruit when it ripens. In this study, the mangaba (Hancornia speciosa Gomes) fruit was harvested at half-ripe and ripe stages of maturity and analyzed for its volatile components. The extracts were obtained from the fruit pulp by using simultaneous distillation and extraction technique. Several extraction parameters such as weight of the pulp, dilution with water, solvent volume and extraction period were standardized to obtain highly characteristic fruit aroma extracts. The extracts were analyzed for the identification of volatile compounds by using a system of high resolution gas chromatograph coupled with mass spectrometer. Eighty-six components were separated out of which 46 compounds were positively identified. The volatile flavoring substances pertaining to classes of esters and terpenes increased from 6.19 to $35.487 \%$ and from 7.51 to $10.40 \%$, respectively. The principal volatile compounds present in the pulp of ripe mangaba fruit were isopropyl acetate (19.23\%), 3-hexanol (10.74\%), linalool (7.38\%), ä-limonene (2.43\%), 3-pentanol (3.80\%), 3-methyl 2-buten-1-ol (2.53\%) and furfural (1.52\%). Biogeneration of mangaba flavor is mainly characterized due to the presence of compounds pertaining to esters, aldehydes and terpenes.
\end{abstract}

Keywords: Volatiles, fruit, maturation.

\section{RESUMO}

A maioria de compostos responsáveis pelo aroma de frutas é desenvolvido durante o estádio de maturação 'maduro'. As frutas da mangabeira (Hancornia speciosa Gomes), colhidas nos estádios de maturação - verde-maduro e maduro, foram analisados quanto aos seus componentes aromáticos a partir de extratos obtidos por meio da destilação

\footnotetext{
${ }^{1}$ Professor Doutor Engenharia Química, Universidade Federal de Sergipe, Sergipe, e-mail: narendra@ufs.br.

${ }_{2}^{2}$ Mestre em Ciência e Tecnologia de Alimentos, Departamento de Engenharia Química, Universidade Federal de Sergipe.

${ }^{3}$ Embrapa Transferência de Tecnologia, Campina Grande, PB.

${ }^{4}$ Professora Doutora, Departamento de Química, Universidade Federal de Pernambuco, 50670-901, Recife, PE.
} 
e extração simultânea. As condições do processo da extração tais como peso da polpa, diluição com água, volume de solvente e o tempo de extração foram estabelecidas para manter as características aromáticas da polpa. Os extratos obtidos foram identificados através de análises realizadas em cromatografo gasoso de alta resolução acoplado a espectrômetro de massa. Oitenta seis compostos foram separados, dentre dos quais, 46 positivamente identificados. As classes de compostos que aumentaram os seus teores durante o amadurecimento da fruta foram de ésteres e terpenos, sendo de 6,19 a $35,487 \%$ e de 7,51 a $10,40 \%$, respectivamente. Os principais compostos voláteis presentes na polpa da mangaba do estádio de maturação 'maduro' foram acetato isopropílico $(19,23 \%)$, 3-hexanol $(10,74 \%)$, linalol $(7,38 \%)$, ä-limoneno $(2,43 \%), 3-$ pentanol (3,80\%), 3-metil 2-buten-1-ol (2,53\%) e furfural (1,52\%). Assim sendo, a biogeração do aroma da fruta de mangabeira é devido à formação de compostos ésteres,

aldeídos e terpenos.

Palavras-chave: Voláteis, fruta, maturação.

\section{INTRODUCTION}

The plant, Mangabeira (term referred for trees of mangaba fruit) is native to the northeast region of Brazil where it has proliferated spontaneously in the uncultivated highland tabuleiros. The fruits, being the size of plums, are eaten without leaving anything although it may contain 2 to 10 small seeds). Although the fruit possesses a little sticky or gummy characteristic, it is known for its attractive appearance, yellowish-green in color, nutritional quality, pleasing aroma and flavor characteristics which are very much appreciated for its consumption (NARAIN, 1990; VIEIRA NETO, 1994; LORENZI, 1998).

Tropical fruits are very much cherished due to their strong exotic aroma. Aroma development in fruits is accompanied by maturation process which involves many changes such as metabolic reactions of synthesis and degradation of many substances. Aroma and taste are determining factors for selection of fruits. The basic taste of mangaba pulp is due to the non-volatile components such as sugars and organic acids. However, the characteristic flavor is attributed to a large number of volatile compounds which are present in extremely small concentrations such as ppm or ppb.

There has been only one work reported on the identification of volatile compounds in mangaba fruit at different stages of maturity (SAMPAIO \& NOGUEIRA, 2006). In this work, the volatile compounds were obtained by hydrodistillation using at clevenger type apparatus. They reported the presence of only 34 compounds in the pulp of mature fruits. However, there are different methods of extracting volatile flavoring compounds. One of the most conventional methods of extracting volatiles is by simultaneous distillation and extraction technique using the Likens \& Nickerson apparatus. It was the purpose of this work to study the generation of volatile compounds in the half-ripe and ripe stages of mangaba fruit by using the Likens \& Nickerson apparatus for the extraction of these compounds.

\section{MATERIALS AND METHODS}

Mangaba fruits were harvested from a farm situated in the city of Itaporanga d'Ajuda in the State of Sergipe. The fruits were harvested at half-ripe and ripe stages of maturation, according to the physiological status and fruit use (NARAIN, 1990). The fruits considered as that of ripe stage in this study were the ones collected from the ground which have naturally fallen from the tree. The fruits were transported to the laboratory in the city of São Cristovão in small cardboard boxes and did not have any 
application whatsoever of inhibitor or accelerator for the control of maturation. Fruits free from any apparent skin damage were selected for analysis. The solvents and authentic standard flavor compounds used in volatiles identification were of pure grade (purity $>97.7 \%$ ) of Merck and Sigma/Aldrich companies, respectively.

\section{Volatiles Isolation}

The volatile compounds were extracted using (LIKENS \& NICKERSON, 1964) apparatus, which applies the simultaneous distillation and extraction technique. The fruit, after being washed with distilled water, was cooled to $2^{\circ} \mathrm{C}$. The skin and kernel were separated manually by using a stainless steel knife and the pulp macerated. The extraction conditions were initially optimized by varying the parameters such as pulp weight (100, $150,200 \mathrm{~g})$, volume of water used for dilution $(100,150,200,250,300 \mathrm{ml})$, solvent (hexane or a mixture of pentane and ethyl ether) and extraction period $(40,50,60,70$, $80 \mathrm{~min}$ ) with the objective to separate a large number of compounds on chromatographic analyses. The volatile extracts were finally obtained at optimized conditions by usage of $150 \mathrm{~g}$ of pulp diluted with $150 \mathrm{ml}$ of distilled water and extraction performed with $20 \mathrm{ml}$ of pentane-ethyl ether (2:1) for $60 \mathrm{~min}$. The extracts were concentrated to a final volume of $0.3 \mathrm{ml}$ under the flow of nitrogen gas.

\section{High Resolution Gas Chromatography/ Mass Spectrometry}

A combined system of Varian gas chromatograph (GC 3800) coupled with mass spectrometer (Saturn 2000R) and the workstation was used. Five microliters of the concentrated volatile extract were injected in the column in a split (1:50) mode. Capillary GC investigations were carried out on a 30 $\mathrm{m}$ (length) $\times 0.25 \mathrm{~mm}$ (internal diameter) innophase bondable polyethylene glycol polar capillary column (HP-INNOWax; 0.25 ì.m film thickness; Hewlett Packard, Inc., Palo Alto, USA). The carrier gas used was helium and column head pressure was maintained at 11.5 psi having a flow rate of $1 \mathrm{ml} / \mathrm{min}$. The oven temperature was programmed: initiation at $30^{\circ} \mathrm{C}$ for $5 \mathrm{~min}$, increased at $7^{\circ} \mathrm{C} /$ min to $100^{\circ} \mathrm{C}$, maintained at $100^{\circ} \mathrm{C}$ for $5 \mathrm{~min}$, increased at $1^{\circ} \mathrm{C} / \mathrm{min}$ to $130^{\circ} \mathrm{C}$, increased at $10^{\circ} \mathrm{C} / \mathrm{min}$ to $195^{\circ} \mathrm{C}$ wherein maintained for $45 \mathrm{~min}$. The temperatures of the injection port and the GC/MS interface were $175^{\circ} \mathrm{C}$ and $195^{\circ} \mathrm{C}$, respectively. The mass spectrometer was operated in the electron ionization mode with an electrical energy of $70 \mathrm{eV}$ and an ion source temperature of $250^{\circ} \mathrm{C}$. The mass spectrum was scanned between 33 and 450 atomic mass units at $0.3 \mathrm{sec}$ interval.

\section{Compounds Identification}

The linear retention index (RI) values for unknowns were determined based on retention time data obtained by analyzing a series of normal alkanes $\left(\mathrm{C}_{8}-\mathrm{C}_{21}\right)$. Volatile components were positively identified by matching their RI values and mass spectra with those of standards, also run under identical chromatographic conditions in the laboratory.

\section{RESULTS AND DISCUSSION}

Table $1 \mathrm{a}$ and $\mathrm{b}$ list the volatile compounds identified in the pulp of mangaba fruits harvested at half-ripe and ripe stages of maturation. The data lists the retention indices and peak area percent values for various compounds identified. It is observed that some compounds have the superscript letter $^{\mathrm{b}}$, which signifies that the compound was tentatively identified since there was no pure standard compound, which could be run under the identical analytical conditions. Thus the identification was considered tentative when it was based mainly on matching an unknown mass spectrum with a spectrum available on the NIST (National Institute of Standards and Technology, USA) mass spectral data system or the literature (JENNINGS \& SHIBAMOTO, 1980; KONDJOYAN \& BERDAGUÉ, 1996). 
Table 1a. Volatile Compounds in Mangaba fruit at half-ripe and ripe stages of maturation.

\begin{tabular}{|c|c|c|c|c|}
\hline \multirow[t]{2}{*}{ No } & \multirow[t]{2}{*}{ Compounds } & \multirow[t]{2}{*}{ RI } & \multicolumn{2}{|c|}{$\begin{array}{l}\text { Peak Area (\%) at different } \\
\text { stages of fruit maturity }\end{array}$} \\
\hline & & & Half-ripe & Ripe \\
\hline \multicolumn{5}{|l|}{ Aldehydes } \\
\hline 1 & Propionaldehyde $\mathrm{a}^{\mathrm{a}}$ & 780 & 0.08 & 0.68 \\
\hline 2 & (Z)-3-nonenal ${ }^{\mathrm{a}}$ & 1345 & 0.45 & 0.24 \\
\hline 3 & Nonanal $^{\mathrm{a}}$ & 1379 & 0.59 & 0.08 \\
\hline 4 & Furfural $^{\mathrm{a}}$ & 1455 & 0.71 & 1.52 \\
\hline 5 & $(E, E)-2,4$-octadienal ${ }^{\mathrm{b}}$ & 1504 & 0.31 & 0.16 \\
\hline 6 & $(E)-2$-nonenal ${ }^{\mathrm{a}}$ & 1518 & 0.37 & 0.03 \\
\hline 7 & $(E)-3$-decenal ${ }^{\mathrm{b}}$ & 1548 & 0.10 & 0.03 \\
\hline 8 & 5-methyl furfural ${ }^{\mathrm{a}}$ & 1586 & 0.39 & 0.04 \\
\hline 9 & m- tolualdehyde ${ }^{a}$ & 1630 & 0.49 & 0.06 \\
\hline 10 & Hexadecanal $^{\mathrm{a}}$ & 2100 & 0.09 & 0.10 \\
\hline \multicolumn{5}{|l|}{ Alcohols } \\
\hline 1 & Ethyl alcohol $^{\mathrm{a}}$ & 930 & 4.71 & 7.61 \\
\hline 2 & 3-pentanol ${ }^{\mathrm{a}}$ & 1113 & 2.41 & 3.80 \\
\hline 3 & 3 -hexanol ${ }^{\mathrm{a}}$ & 1185 & 11.15 & 10.74 \\
\hline 4 & Furfuryl alcohol $^{\mathrm{b}}$ & 1198 & 0.04 & 1.06 \\
\hline 5 & 3-methyl-2-pentanol ${ }^{\mathrm{a}}$ & 1202 & 0.68 & 0.32 \\
\hline 6 & 3-methyl-2-buten-1-ol ${ }^{\mathrm{b}}$ & 1245 & 2.83 & 2.53 \\
\hline 7 & $(E)$-2-penten-1-ol ${ }^{\mathrm{a}}$ & 1315 & 0.12 & 0.28 \\
\hline 8 & 3 -octanol ${ }^{\mathrm{a}}$ & 1383 & 0.08 & 0.03 \\
\hline 9 & $\alpha$ - terpineol $^{\mathrm{a}}$ & 1687 & 1.98 & 0.55 \\
\hline 10 & 1,3-butane diol ${ }^{\mathrm{a}}$ & 1751 & 0.22 & 0.18 \\
\hline 11 & Geraniol $^{\mathrm{a}}$ & 1797 & 0.28 & 0.43 \\
\hline 12 & Benzyl alcohol $^{\mathrm{a}}$ & 1821 & 0.02 & 1.03 \\
\hline 13 & Eugenol $^{\mathrm{a}}$ & 2155 & 0.82 & 0.26 \\
\hline 14 & Tetradecanol $^{\mathrm{a}}$ & 2176 & 0.50 & 0.22 \\
\hline 15 & $p$-isopropyl phenol ${ }^{\mathrm{a}}$ & 2185 & 0.45 & 0.60 \\
\hline \multicolumn{5}{|l|}{ Esters } \\
\hline 1 & Ethyl acetate $^{\mathrm{a}}$ & 819 & & 9.38 \\
\hline 2 & Isopropyl acetate $\mathrm{a}^{\mathrm{a}}$ & 882 & & 19.23 \\
\hline 3 & Diethyl sulfide $^{\mathrm{a}}$ & 903 & & 2.39 \\
\hline 4 & Propyl acetate ${ }^{\mathrm{a}}$ & 966 & 0.23 & 0.30 \\
\hline 5 & Ethyl butyrate $^{\mathrm{a}}$ & 1029 & 0.13 & 0.14 \\
\hline 6 & 2-methylethyl butyrate ${ }^{a}$ & 1042 & 0.45 & 0.40 \\
\hline 7 & Butyl acetate $^{\mathrm{a}}$ & 1065 & 0.32 & 0.16 \\
\hline 8 & Dimethyl disulfide $^{a}$ & 1091 & 0.29 & 0.09 \\
\hline 9 & Isopropyl disulfide ${ }^{\mathrm{b}}$ & 1260 & 0.42 & 0.50 \\
\hline 10 & Cyclohexyl formate $^{\mathrm{b}}$ & 1304 & 0.22 & 0.06 \\
\hline 11 & Hexyl acetate $^{a}$ & 1308 & 0.26 & 0.01 \\
\hline 12 & 2-furfuryl acetate ${ }^{\mathrm{b}}$ & 1514 & 0.14 & 0.24 \\
\hline 13 & $(E)$-5-decenyl acetate ${ }^{\mathrm{b}}$ & 1721 & 0.43 & 0.29 \\
\hline 14 & Linalyl hexanoate ${ }^{\mathrm{b}}$ & 1844 & 1.29 & 1.02 \\
\hline 15 & Isobutyl cinnamate ${ }^{\mathrm{b}}$ & 2230 & 0.46 & 0.52 \\
\hline 16 & Heptylphenyl acetate ${ }^{\mathrm{b}}$ & 2266 & 0.25 & 0.55 \\
\hline 17 & Methyl octadecanoate ${ }^{a}$ & 2429 & 0.69 & 0.18 \\
\hline 18 & Ethyl octadecanoate $^{\mathrm{a}}$ & 2464 & 0.61 & 0.02 \\
\hline
\end{tabular}


Table 1 b. Aromatic Compounds in Mangaba fruit at half-ripe and ripe stages of maturation.

\begin{tabular}{|c|c|c|c|}
\hline \multicolumn{4}{|c|}{ Aromatic compounds } \\
\hline 1 & Benzene $^{a}$ & $924 \quad 3.84$ & 0.34 \\
\hline 2 & Toluene $^{a}$ & 10260.17 & 0.11 \\
\hline 3 & $m$-xylene ${ }^{\mathrm{a}}$ & 11211.28 & 0.07 \\
\hline 4 & $o$-xylene $^{\mathrm{a}}$ & 11630.60 & 0.06 \\
\hline 5 & 1,3,5-trimethyl benzene & 12401.24 & 0.04 \\
\hline \multicolumn{4}{|c|}{ Ketones } \\
\hline 1 & 1-penten-3-one ${ }^{\mathrm{a}}$ & 10140.93 & 0.10 \\
\hline 2 & 3-hexanone ${ }^{a}$ & 10490.09 & 0.04 \\
\hline 3 & 3-hydroxy-2-butanone ${ }^{b}$ & 12752.22 & 0.36 \\
\hline 4 & Isoamyl ketone $^{b}$ & 15290.29 & 0.03 \\
\hline 5 & Acetophenone $^{\mathrm{a}}$ & 16111.13 & 0.20 \\
\hline \multicolumn{4}{|c|}{ Terpenes } \\
\hline 1 & $\delta$-limonene ${ }^{\mathrm{a}}$ & 1181 & 2.43 \\
\hline 2 & $(E)$-linalool oxide ${ }^{\mathrm{a}}$ & 14240.74 & 0.37 \\
\hline 3 & Linalool $^{\mathrm{b}}$ & 15376.69 & 7.38 \\
\hline 4 & $\alpha$ - phellandrene ${ }^{\mathrm{a}}$ & 17450.08 & 0.22 \\
\hline \multicolumn{4}{|c|}{ Lactones } \\
\hline 1 & $\alpha$-angelica lactone ${ }^{\mathrm{a}}$ & 14300.24 & 0.14 \\
\hline 2 & $\gamma$-valerolactone ${ }^{\mathrm{a}}$ & 16160.33 & 0.30 \\
\hline 3 & $\chi$-undecalactone ${ }^{\mathrm{b}}$ & 22140.39 & 0.44 \\
\hline \multicolumn{4}{|c|}{ Acid } \\
\hline 1 & Dodecanoic acid $^{\mathrm{b}}$ & 25142.10 & 0.28 \\
\hline
\end{tabular}

a - identified positively based on retention index datum and spectrum verification from the NIST mass library or literature (ADAMS, 1995; JENNINGS \& SHIBAMOTO 1980) along with the standards run under identical analytical conditions.

${ }^{b}$ - identified tentatively based on retention index datum and spectrum verification from the NIST mass library or literature (ADAMS, 1995; JENNINGS AND SHIBAMOTO 1980)

In a typical chromatogram analyzed for the volatile extracts obtained from pulp of different maturities of mangaba fruit, a total number of 86 components were separated out of which, 46 compounds were positively identified and 15 tentatively identified. The other components could not be identified. Among the identified components in the the pulp of ripe mangaba fruit were 18 esters representing an area of $35.48 \%, 15$ alcohols $(29.64 \%), 4$ terpenes $(10.40 \%), 10$ aldehydes, $(2.94 \%)$ and 5 ketones $(0.73 \%)$.

The main volatile compounds positively identified in the pulp of half-ripe mangaba fruit were 3 -hexanol $(11.15 \%)$, linalool $(6.69 \%)$, ethyl alcohol $(4.71 \%)$, benzene (3.84\%), 3-pentanol (2.41\%), á-terpineol (1.98\%), ã-undecalactone (0.39\%), $m$-xylene
$(1.28 \%)$, acetophenone $(1.13 \%)$ while dodecanoic acid $(2.10 \%)$ was tentatively identified. The aroma note of 3-hexanol is characterized as alcoholic, ethereal and medicinal while that of phenylacetaldehyde is known to be harsh. Among the other aldehydes, which are characteristic of sweet, fruity and floral notes, present in the pulp at this stage of fruit maturity were 3-nonenal, nonanal, furfural, 3-decenal, tolualdehyde, and hexadecanal. Although 15 esters were identified but their total concentration was very low $(6.19 \%)$ as compared to fully ripe fruits. SAMPAIO \& NOGUEIRA (2006) reported the presence of 3-methyl-3-buten1-ol (6.8\%); 3-methyl-3-buten-1-yl acetate $(5.4 \%)$, ethyl propanoate $(4.1 \%)$ and (Z)-3hexenol $(3.2 \%)$ as principal compounds in 
the pulp of half-ripe fruit. However, these compounds were not found in this study based on extraction procedure using Likens \& Nickerson's apparatus.

The ripe fruits contained 18 esters and their total concentration was quite representative, being $35.48 \%$. This data proves that aroma biogeneration in mangaba fruit has much to do with esters formation. The physiology of flavor formation is derived from the metabolic changes during maturation of fruits. In the pulp of ripe mangaba fruit, the positively identified esters which were not found in the pulp of half-ripe fruit were ethyl acetate (9.38\%), isopropyl acetate $(19.23 \%)$ and diethyl sulfide $(2.39 \%)$. The concentration of all these esters increased in the pulp of ripe fruit. It may hence be concluded that the generation of these compounds could lead to character-impact mangaba fruit aroma. Ethyl acetate is one of the most prominent compounds used in the preparation of flavor chemicals. It constitutes a major part of imitation flavors of many berry-type fruits, banana, grape, pineapple, peach, lemon, Tutti-frutty, almond, butterscotch, whisky, butter, mint, pear, melon etc. (ARCTANDER, 1969). The pronounced increase in the concentration of ethyl acetate and isopropyl acetate in pulp of ripe fruit as compared to that of the half-ripe fruits proves that these compounds could be responsible for the characteristic aroma of mangaba pulp. SAMPAIO \& NOGUEIRA (2006) reported the presence of 3-methyl-3-buten1-yl acetate (28.2\%), 3-methyl 3-buten-1-ol (12.1\%); 3-methyl-1-butanyl acetate (8.8\%) and 3-methyl-1-butanol (5.2\%), compounds which were not found in this study. However, compounds such as 3-hydroxy-2-butanone $(9.1 \%)$, and furfural ( $8.3 \%)$ were also found in the pulp of the ripe fruit in this study.

The main compounds identified in the pulp of ripe mangaba fruits and which were quantitatively representing higher peak area in chromatogram were isopropyl acetate (19.23\%), 3-hexanol (10.74\%), ethyl acetate $(9.38 \%)$, ethyl alcohol $(7.61 \%)$, linalool (7.38\%), 3-pentanol (3.80\%), 3-methyl-2butenol (2.53\%), ä-limonene (2.43\%), furfural
(1.52\%) and benzyl alcohol (1.03\%). Since most of these compounds although belonging to different organic classes such as esters, alcohols, terpenes and aldehydes are known to possess characteristic sweet, floral, creamy and fruity odors representing different fruits, it could be concluded that these prominent compounds could contribute to a great extent the characteristic volatile flavor of mangaba fruit. The ripe mangaba fruits used in this study were the ones which have naturally fallen from tree and hence the maturity stage of these fruits was very close to the point of climacteric rise in fruit respiration wherein most of the volatile flavoring substances are generated.

The esters in fruits are usually formed from the â-oxidation of unsaturated fatty acids or from the reaction of alcohols and acids which are derived from common amino acids such as valine, leucine, cysteine and methionine. The increase in ethanol concentration occurs during the maturation stage of fruit development when acidity decreases, total soluble solids increase and the flavor compounds increase to characteristic aroma in ripe stage of the fruit. Acids and ketones and other intermediate compounds involved in the oxidation process of lipids are readily converted to alcohols, aldehydes and esters by enzyme systems such as acyl thiokinase, acyl-CoA-alcohol transacylase, acyle-CoA reductase and alcohol-NAD oxydoreductase (TRESSL \& DRAWERT, 1973).

Although in low concentrations, the presence of lactones such as á-angelica lactone, ã-valerolactone and ãundecalactone was observed in fruits during development. These lactones mostly represent peach-like aroma and were also present in mango fruit cultivar Tommy Atkins grown in Vale de São Francisco, in the northeast region of Brazil (NARAIN \& GALVÃO, 2004). 


\section{CONCLUSIONS}

This research reports the volatiles profile of mangaba fruits at half-ripe and ripe stages of its maturation. During the fruit development, there was a pronounced increase in esters compounds, varying from $6.19 \%$ in half-ripe fruits to $35.48 \%$ in ripe fruits. Isopropyl acetate, ethyl acetate, 3hexanol, ethyl alcohol, linalool, 3-pentanol, 3methyl-2-butenol, furfural and ä-limonene are

\section{REFERENCES}

ADAMS R.P. Identification of essential oil Components by gas chromatography/mass spectroscopy. Chicago: Allured Publishing Corporation, 1995.

ARCTANDER, S .Perfume and flavor chemicals (aroma chemicals). New Jersey: Montclair, 1969.

JENNINGS, W.G.; SHIBAMOTO,T. Qualitative analysis of flavor and fragrance volatiles by glass capillary gas chromatography. New York: Academic, 1980. $472 p$

KONDJOYAN, N.; BERDAGUÉ, J.L. A compilation of relative retentive indices for analysis of aromatic compounds. Champanelle: Laboratóire Flaveur, 1996. 231p.

LIKENS, S.T.; NICKERSON, G.B. Detection of certain hop oil constituents in brewing products. Proceedings of the American Brewing Chemists, Bensenville, IL, v.5, n.5, p.5-13, 1964. suggested as prominent compounds responsible for the characteristic aroma of mangaba fruit.

\section{ACKNOWLEDGEMENTS}

One of the authors (N.N.) thanks to Conselho Nacional de Desenvolvimento Científico e Tecnologico (CNPq), Brazil for awarding a fellowship for a research project under which this work was accomplished.
LORENZI, H. Árvores Brasileiras: manual de identificação e cultivo de plantas nativas do Brasil. Nova Odessa: Plantarum. 1998. p.28-322.

NARAIN, N. Mangaba. In: NAGY, S., SHAW, P.E., WARDOWSKI, W.F. (Eds.). Fruits of tropical and subtropical origin: composition, properties and uses. Lake Alfred: FSS, 1990. p.159-165

NARAIN, N.; GALVÃO, M.S. Volatile aroma compounds in mango fruit cV. 'Tommy Atkins' - A preliminary study. Acta Horticulturae, n.645, p.671-676. 2004.

TRESSL, R.; DRAWERT, F. Biogenesis of banana volatiles. Journal of Agriculture and Food Chemistry, n. 21, p.560-575, 1973.

SAMPAIO,T.S.; NOGUEIRA,P.C.L. Volatile components of mangaba fruit (Hancornia speciosa Gomes) at three stages of maturity. Food Chemistry, n. 95, p. 606-610, 2006. 